\title{
PENGEMBANGAN BAHAN AJAR STATISTIKA ELEMENTER MENGGUNAKAN APLIKASI MINITAB
}

\author{
Mira Meilisa ${ }^{1 *}$, Lely Kurnia ${ }^{2}$ \\ ${ }^{1}$ Prodi Teknik Elektro Universitas Muhammadiyah Sumatera Barat \\ ${ }^{2} J u r u s a n$ Tadris Matematika Fakultas Tarbiyah dan Ilmu Keguruan IAIN Batusangkar \\ *Email: mirameilisa@umsb.ac.id
}

\begin{abstract}
Amendment and development of education in Indonesia today requires various elements of education to participate in improving the quality of graduates to be able to compete in the global world. Indonesia was ranked 34th away from Singapore, Malaysia, Japan and Korea in the 20th position. This is because the educational institutions in Indonesia have not been able to produce graduates who are capable, superior, competeable with others. The educational tertiary education institution (LPTK) as one of the teacher producing institution has not been able to create prospective teacher who are ready to teach. The characteristic of the lecture process that is stated in Permenristek Dikti no. 44 of 2015 is interactive, holistic, integrative, scientific, contextual, thematic, effective, collaborative and student-centered. One way to realize this is to develop teaching materials that are used in applicable and communicative lectures. Based on the phenomenon, the researchers conducted research and development. In this study, researchers produce the elementary statistical teaching materials using the Minitab application by following Borg \& Gall's research and development steps, namely (1) Carrying out information gathering (2) Designing (3) Develop the initial product form (4) Conduct pilot field trials. If can be concluded that the research on the development of statistical teaching materials that have produced valid products and can be used in lectures to develop student creativity. This development research should be continued in the next stage, namely the product effectiveness stage.
\end{abstract}

Keywords: Statistics elementer, teaching materials, minitab application, student creativity, development education.

\section{PENDAHULUAN}

Association

$$
\text { for }
$$

Educational

Communications and Technology (AECT) mendefinisikan teknologi pendidikan sebagai suatu proses rumit, terpadu yang melibatkan manusia, prosedur, gagasan, rancangan dan pengorganisasian dalam menganalisis, merancang, melaksanakan, mengevaluasi serta mengelola pemecahan masalah tindak belajarnya manusia dari segala aspek (Sudjana, 2005). Pemecahan masalah secara teknologi pendidikan menyangkut segala macam sumber belajar, baik yang direncanakan dan dipilih maupun yang dimanfaatkan untuk kegiatan belajar.
Sumber belajar adalah informasi yang disajikan dan disimpan dalam berbagai bentuk media, yang dapat membantu siswa (mahasiswa) dalam belajar sebagai perwujudan dari kurikulum. Sumber belajar dapat berbentuk tempat atau lingkungan, orang, benda, buku, dan peristiwa (Majid, 2006). Bahan ajar merupakan salah satu bagian dari sumber belajar yang dapat diartikan sebagai sesuatu yang mengandung pesan pembelajaran, baik yang diniatkan secara khusus maupun bersifat umum yang dapat dimanfaatkan untuk kepentingan pembelajaran. Dengan kata lain bahan ajar adalah segala bentuk bahan yang digunakan untuk membantu guru, dosen atau instruktur dalam melaksanakan 
kegiatan pembelajaran di kelas. Bahan ajar berisi tentang ilmu pengetahuan yang dapat digunakan oleh peserta didik untuk belajar, kamus menjelaskan istilah-istilah dari ilmu pengetahuan itu sendiri, dan seterusnya. Jadi, jelas bahwa bahan ajar sangat membantu dan memudahkan mahasiswa dalam belajar.

Bahan ajar merupakan komponen penting dalam pembelajaran. Bahan ajar yang disampaikan seorang pendidik hendaknya mengacu kepada tujuan yang telah digariskan dalam kurikulum. Sebagaimana salah satu capaian pembelajaran yang dirumuskan dalam kurikulum KKNI Jurusan Tadris Matematika, yaitu mahasiswa dituntut untuk mampu mengambil keputusan yang tepat berdasarkan informasi dan data dalam penyelenggaraan pendidikan yang relevan, mampu mengkaji data dan informasi untuk menentukan pilihan terbaik dari solusi yang telah ada di bidang pendidikan secara mandiri dan kelompok sebagai dasar pengambilan keputusan. Statistika Elementer merupakan salah satu mata kuliah yang relevan untuk memenuhi capaian pembelajaran tersebut, dimana mata kuliah ini merupakan mata kuliah wajib dalam rumpun kompetensi utama dalam kurikulum inti. Mata kuliah ini memuat materimateri dasar dalam penyajian, pengolahan data penelitian sampai pada pengambilan keputusan. Untuk memenuhi capaian pembelajaran yang dimaksudkan di atas harus didukung oleh semua perangkat pembelajaran, salah satunya adalah bahan ajar.

Seiring berkembangnya teknolologi informasi dan kebutuhan akan pengambilan keputusan yang cepat dan tepat, penggunaan software statistik cukup penting untuk dijadikan bahan kajian utama pada mata kuliah statistika elementer. Salah satu software statistik yang friendly digunakan dalam pengolahan data statistic adalah software Minitab. Minitab adalah program untuk melakukan pengolahan statistik. Minitab mengkombinasikan kemudahan penggunaan layaknya Microsoft Excel dengan kemampuannya melakukan analisis statistik yang komplek. Penggunaan Minitab dapat dikatakan cukup mudah dengan berbagai macam fitur pengolahan data yang cukup banyak.

\section{METODE PENELITIAN}

Sesuai dengan permasalahan yang akan diteliti, maka jenis penelitian yang digunakan adalah jenis penelitian pengembangan (development research). Rancangan penelitian di atas digambarkan dalam prosedur penelitian yang dapat seperti bagan pada Gambar 1.

\section{HASIL DAN PEMBAHASAN}

Setelah bahan ajar Statistika elementer dirancang, kemudian dilakukan tahap validasi. Bahan ajar statistika dengan aplikasi minitab ini divalidasi oleh 2 validator. Validator dipilih berdasarkan bidang keahlian statistika. Peneliti meminta validator mengisi lembar validasi dan memberikan saran dan perbaikan terhadap bahan ajar. Hasil validasi bahan ajar dari masingmasing validator yang telah diolah dapat dilihat pada Tabel 1. 
Meilisa, M., Kurnia, L. 2018. Pengembangan Bahan Ajar Statistika Elementer Menggunakan Aplikasi Minitab. Sainstek : Jurnal Sains dan Teknologi. 10 (2) : 63-67

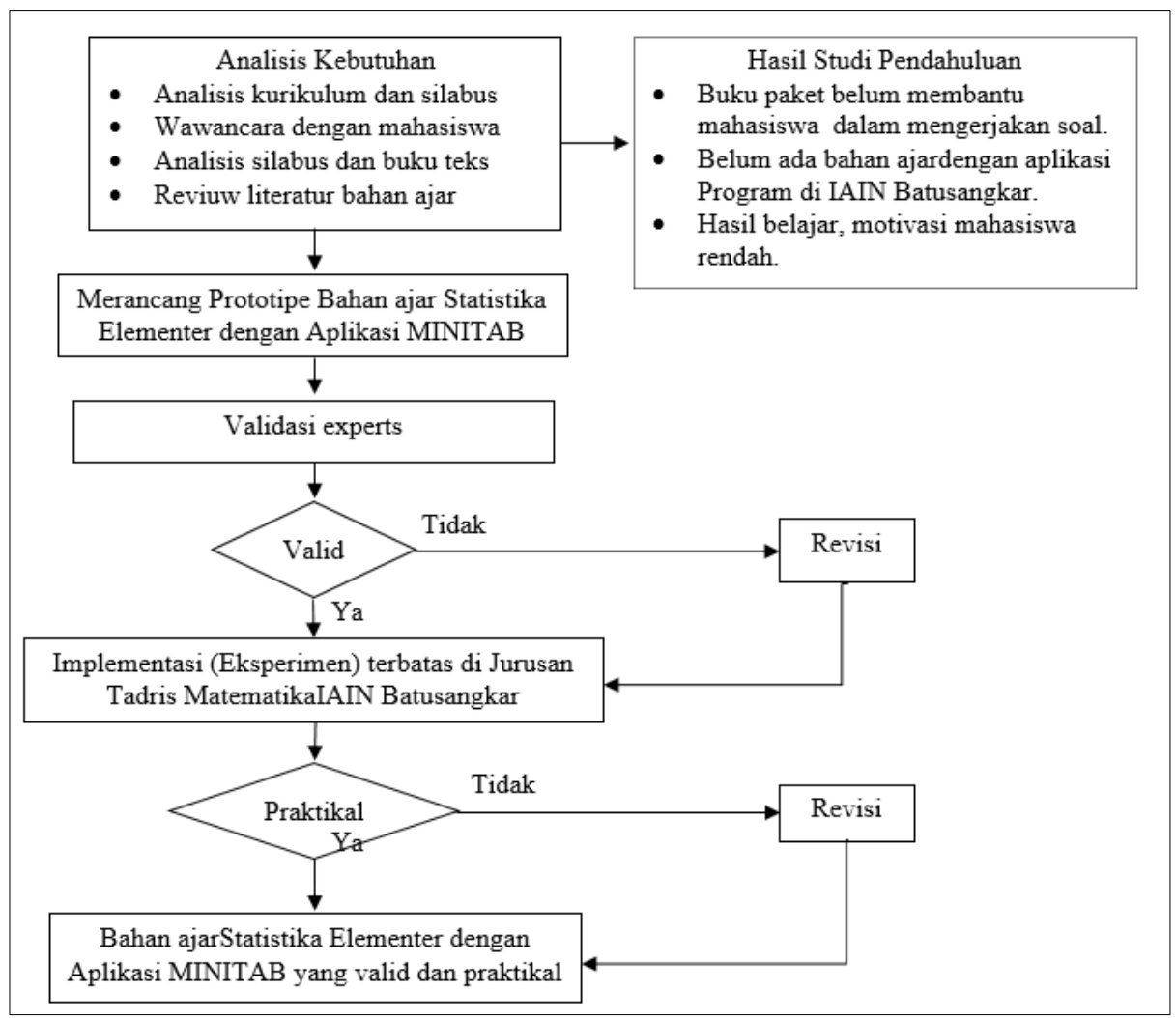

Gambar 1. Prosedur Penelitian

Tabel 1. Data Hasil Validasi Bahan Ajar Statistika Elementer dengan Aplikasi Minitab

\begin{tabular}{|c|c|c|c|c|c|c|c|}
\hline \multirow{2}{*}{ No. } & \multirow{2}{*}{ Aspek } & \multicolumn{2}{|c|}{ Validator } & \multirow{2}{*}{$\mathrm{Jml}$} & \multirow{2}{*}{$\begin{array}{c}\text { Skor } \\
\text { Maks }\end{array}$} & \multirow{2}{*}{$\%$} & \multirow{2}{*}{ Kategor } \\
\hline & & 1 & 2 & & & & \\
\hline 1. & Kelayakan Isi & 29 & 32 & 61 & 72 & 84.7 & Sangat valid \\
\hline 2. & Kelayakan Penyajian & 35 & 35 & 70 & 80 & 87.5 & Sangat valid \\
\hline 3. & Kelayakan Bahasa & 14 & 15 & 29 & 32 & 90.6 & Sangat valid \\
\hline \multirow[t]{2}{*}{4.} & Kelayakan kegrafikan & 21 & 23 & 44 & 56 & 78.6 & Valid \\
\hline & Jumlah & 99 & 105 & 204 & 240 & 85 & Sangat valid \\
\hline
\end{tabular}

Tabel 2. Hasil Angket Respon Mahasiswa terhadap Kepraktisan Bahan Ajar Statistika Elementer dengan Aplikasi Minitab.

\begin{tabular}{llllrl}
\hline No. & \multicolumn{1}{c}{ Indikator } & Jumlah & Skor Maks & $\%$ & \multicolumn{1}{c}{ Kriteria } \\
\hline 1. & Petunjuk & 186 & 240 & 77.5 & Praktis \\
2. & Isi & 474 & 560 & 84.6 & Sangat praktis \\
3. & Kemudahan penggunaan & 504 & 640 & 78.7 & Praktis \\
\hline \multicolumn{2}{c}{ Jumlah } & 1169 & 1440 & 81.18 & Sangat praktis \\
\hline
\end{tabular}


Hasil yang diperlihatkan pada Tabel 1 menggambarkan bahwa bahan ajar Statistika Elementer dengan Aplikasi Minitab sangat valid. Bahan ajar yang dirancang dinilai sudah valid dari segi isi materi Statistika Elementer, dan aplikasinya pada program minitab. Penyajian bahan ajar sudah lengkap sesuai dengan format bahan ajar, konsisten dalam penggunaan istilah dan ilustrasi yang diberikan membantu penjabaran materi. Bahasa yang dipakai sudah komunikatif dan sesuai dengan kaidah Bahasa Indonesia yang baik dan benar. Tampilan bahan ajar dinilai sudah standar dari segi ukuran, konsisten. Jadi bahan ajar Statistika Elementer dengan Aplikasi Minitab sudah sahih menurut pendapat validator.

Berdasarkan saran-saran validator, peneliti melakukan perbaikan terhadap bahan Ajar Statistika Elementer dengan Aplikasi Minitab. Untuk melihat kepraktisan bahan ajar statistika elementer dengan aplikasi minitab dilakukan uji coba terbatas pada 20 orang mahasiswa jurusan Tadris Matematika semester III, dimana mahasiswa ini sedang mengambil mata kuliah Statistika Elementer, namun belum memasuki materi yang memanfaatkan aplikasi minitab. Pada uji coba terbatas ini, mahasiswa diminta membaca dan mempelajari bahan ajar yang telah dibagikan untuk selanjutnya diminta mengisi angket respon. Skor hasil angket respon mahasiswa disajikan dalam Tabel 2 .

Berdasarkan data pada Tabel 2 terlihat bahwa bahan ajar statistika elementer dengan aplikasi minitab dinilai praktis dari segi petunjuk dan kemudahan penggunaan, sangat praktis dari segi isi. Dengan adanya bahan ajar ini, materi statistika elementer menjadi lebih menarik dan kemudahan dalam penyelesaian masalah karena pada bahan ajar, suatu masalah diselesaikan dengan menggunakan perhitungan manual sekaligus disertai pengolahan data menggunakan software statistik yaitu minitab. Pada software minitab, prosedur yang digunakan macro minitab mengiring mahasiswa kepada langkahlangkah logis dari konsep statistik tersebut.

Berdasarkan analisis kurikulum dan silabus mata kuliah Statistika Elementer, dibutuhkan referensi atau sumber belajar bagi mahasiswa, sehingga kompetensi yang dirumuskan pada silabus dan juga profil lulusan yang sudah dirancang dapat tercapai. Dengan adanya bahan ajar ini, membantu mahasiswa untuk memahami materi statistika elementer sekaligus melatih mahasiswa untuk bisa terampil menggunakan software statistik dalam penyelesaian masalah. Sehingga dapat disimpulkan bahwa dengan bahan ajar yang dirancang diharapkan mahasiswa mampu belajar secara mandiri, dengan kata lain, kompetensi yang dirumuskan sesuai dengan silabus maupun profil lulusan yang diharapkan dapat tercapai, meskipun tidak semua materi dapat tersampaikan pada perkuliahan.

Prototipe bahan ajar Statistika Elementer dengan Aplikasi Minitab yang dirancang sesuai d engan komponen-komponen bahan ajar yang telah ditetapkan. Bahan ajar ini memiliki tiga komponen yaitu :

1. Pendahuluan

a. Learning Outcomes yang memuat SK, $\mathrm{KD}$ dan indikator dibuat satu lembar pada lembaran awal bagian bahan ajar

\section{b. Peta konsep}

2. Penulisan/ isi setiap bab bahan ajar yang terdiri dari Tujuan Pembelajaran, Materi Pokok, Uraian Materi dan Latihan.

3. Daftar pustaka

Hasil Validasi Bahan Ajar Statistika Elementer dengan Aplikasi Minitab

Berdasarkan deskripsi hasil validasi dari validator, pertanyaan penelitian "Bagaimana validitas dari bahan ajar Statistika Elemneter dengan Aplikasi Minitab?" telah terjawab. Deskripsi hasil validasi tersebut diatas menunjukkan bahwa bahan ajar Statistika Elementer dengan Aplikasi Minitab yang peneliti rancang sudah valid dengan melakukan perbaikan sesuai dengan saran dari validator.

Menurut penilaian validator, bahan ajar Statistika Elementer dengan Aplikasi Minitab sudah valid, namun butuh beberapa revisi sederhana untuk diperbaiki. Isi bahan ajar Statistika Elementer dengan Aplikasi Minitab secara umum dinilai sudah sangat valid sesuai dengan format baku. Materi yang dijabarkan memuat substansi minimal (konsep, prinsip, prosedur, teori dan fakta) yang mendukung seluruh pencapaian kompetensi dasar. Materi 
pembelajaran yang dipilih untuk diajarkan oleh pendidik di satu pihak dan harus dipelajari peserta didik di lain pihak hendaknya berisikan materi pembelajaran yang benar-benar menunjang tercapainya standar kompetensi dan kompetensi dasar. Dengan demikian, materi yang dipaparkan dalam bahan ajar harus sesuai dengan kompetensi yang hendak dicapai. Untuk kelayakan penyajian bahan ajar statistika elementer dengan aplikasi minitab dinilai sudah sangat valid. Penyajian bahan ajar ini sudah sesuai dengan format bahan ajar yang telah ditetapkan yaitu : Pendahuluan yang berisi peta konsep dan learning outcomes, isi masingmasing bab dan daftar pustaka. Dari segi kelayakan bahasa, bahan ajar statistika elementer dengan aplikasi minitab dinilai sangat valid dari segi ketepatan tata bahasa dan kesesuaian dengan perkembangan mahasiswa. Untuk kelayakan grafik, bahan ajar ini dinilai valid dari segi ukuran ukuran dan disain bahan ajar. Bahan ajar statistika elementer dengan Aplikasi Minitab sudah praktis berdasarkan angket respon mahasiswa. Menurut (Daryanto, 2013), keterbacaan dari suatu bahan ajar diindikasikan oleh beberapa aspek, diantaranya : (1) Pemahaman yang tepat mengenai isi bahan ajar, (2) tingkat kemampuan pembaca atau kelompok sasaran, (3) penggunaan bahasa bahan ajar.

\section{KESIMPULAN}

Penelitian ini telah menghasilkan sebuah bahan ajar Statistika Elementer dengan
Aplikasi Minitab yang valid dan praktis dengan rincian sebagai berikut :

1. Bahan ajar ini sangat valid menurut 2 orang pakar dari segi kelayakan isi, kelayakan penyajian, kelayakan bahasa, dan kelayakan kegrafikan.

2. Hasil uji coba pada 20 orang mahasiswa pada semester III diperoleh bahan ajar Statistika Elementer dengan Aplikasi Minitab yang praktis dari segi keterbacaan untuk indikator petunjuk, bahasa dan kemudahan penggunaan .

\section{DAFTAR KEPUSTAKAAN}

Daryanto. (2013). Menyusun Modul Bahan Ajar untuk persiapan Guru dalam Mengajar. Yogyakarta: Gava Media.

Majid, A. (2006). Perencanaan Pembelajaran Mengembangkan Standar Kompetensi Guru. Bandung: PT Remaja Rosdakarya.

Pannen, P., \& Purwanto. (2001). Penulisan Bahan Ajar. Jakarta: Ditjen Dikti Depdiknas.

Sudjana, N. (2005). Penilaian Proses Hasil Belajar Mengajar. Bandung: PT Remaja Rosdakarya.

Widodo, C., \& Jasmadi, S. (2008). Panduan Menyusun Bahan Ajar Berbasis Kompetensi. Jakarta: Elex Media Komputindo. 